\title{
Waardenburg syndrome
}

INSERM

\section{Source}

INSERM. (1999). Orphanet: an online rare disease and orphan drug data base.

Waardenburg syndrome. ORPHA:3440

Waardenburg syndrome (WS) is a disorder characterized by varying degrees of deafness

and minor defects in structures arising from neural crest, including pigmentation

anomalies of eyes, hair, and skin. WS is classified into four clinical and genetic

phenotypes. 